Journal of Siberian Federal University. Humanities \& Social Sciences 6 (2015 8) 1165-1172

УДК 130.3

\title{
Presence of Spirituality in Social Consolidation in the World
}

\author{
Maria V. Kozlova* \\ Siberian Federal University \\ 79 Svobodny, Krasnoyarsk, 660041, Russia
}

Received 12.11.2014, received in revised form 12.01.2015, accepted 14.04.2015

\begin{abstract}
The author makes an attempt to analyse from social and philosophical sides potential of actions against information terrorist threats of these days by the means of influence on processes of consolidation in the Russian society. As the result of this work, a conclusion about specific relation between consolidating ideas prevailing in the society and the level of resistance to destructive manipulative influence of terrorists (or ideologists of violence) is drawn. These results can be applied as an addition to current recommendations on countering terrorist threats and ensuring social and cultural safety.
\end{abstract}

The formation of social consolidation mechanism lies in resolution of contradictions driven by the nature of social relations between dominance and submission, force and free will, disagreement and agreement. Consolidation is considered to be an essential factor for the existence of society, for its functioning and ability to identification. Provided that, a manner of its implementation depends on different factors such as technological, economical, cultural, historical ones and etc.

For a good understanding of problems related to consolidation (or dissociation) in the Russian society from methodological views and in accordance with research concepts provided by analysts from Irkutsk, we specify two types (streams) of consolidarity: vertical, i.e. an agreement between the government and society and vice versa); and horizontal, i.e. an agreement inside communities and between communities which build up the society. It is important to mention that vertical consolidation depends on deliberate initiative from the power and can be framed at will; a horizontal one has a natural format since can it be represented in a form of everyday engagement.

The article draws attention to the concept of "spirituality" which now has slipped to the periphery of social conscience due to its identification with religiosity, but is still popular in the society as a form of request for moral values or balanced personal development and can so far be kept current.

A special point in the article is given to the fact that a traditional philosophical idea in Russia represents social and philosophical origin of "spirit", "soul" and "spirituality" together with moral duty, with internal self-improvement and changes, with reason and sensibility integrity, freedom and responsibility. Pursuance of unity through unanimity, not by opposition between unity and personal freedom, but through freedom of every soul in its desire to achieve the Spirit is one of the most important part of Russian philosophy.

The author follows the statement that spirituality, within a sufficient development of its concept from social and culturological points of view, may well become ideological principle of horizontal consolidation in modern Russian society, constructed through the system of education as a leading factor in personal life style formation. As a result of complete destruction of mechanism of social development that took place in the anarchic system of 1990s, now we cannot see any shared idea about

(C) Siberian Federal University. All rights reserved

* Corresponding author E-mail address: mko@ngs.ru 
deference between good and evil and also we are unfamiliar to sympathy, justice, sorrow, mercy or kindness.

As it is described in the article, formation of consolidation mechanism holds a number of problems which gather their pace within influence of globalization, social transformations, crises in economical, political, cultural and etc. spheres, appeared subsequently after the destruction of Soviet society where the Russian environment were integrated. After almost quarter of a century since Russia has become independent processes of deconsolidation still exist, i.e. a risk of destruction still exists in many former Soviet republics. For example today's events in Ukraine broadly represent the result of former ties breaking and demonstrate a probable scenario when vertical consolidation mechanisms collapse, determining misbalance of horizontal channel. In this context, attempts from the side of geopolitical powers directly or indirectly supporting Russophobia to plunge post-Soviet areas into an open confrontation are considered to be symptomatic and analysed as a currently important threat reflected in increasing of terrorism acts oriented on destabilization and deconsolidation of the Russian society.

By analyzing later word events the author concludes on the spread of terrorism and its becoming a global source of social entropy. In order to minimize terrorist threats, countermeasures should be brought into action in all spheres according to their variety. This is impossible to achieve without united efforts, building of consolidation mechanisms inside the power and between economical, political, educational and other spheres of social life.

Keywords: ideological principles, solidarity, consolidation, terrorism.

Research area: philosophy.

Before speaking both about destructive forces, endangering social safety, and ways to resist them, a need to define a minimum set of terms insuring an opportunity for the society to be developed by constructive and peaceful solutions of internal system contradictions is emerged.

The process of social consolidation development lies in resolution of contradictions dependent on the nature of social relations between dominance and submission, force and free will, disagreement and agreement. Consolidation is considered to be an essential factor for the existence of society, for its functioning and ability to identification. Thus, a principle of its performance depends on different aspects, such as technological, economical, cultural, historical and many others. Those researches who analyse problems of social interaction, tell the difference between ways of obtaining consolidation and order in society: "intangible and tangible" [7. P. 125]. One ways (tangible) are based on direct violence, threatening and corruption and include force: enemy image creation, affect provoking, promising of material benefits for one social actors to accept uncomplainingly (as uncomplaining acceptance attributes to approaching between subjects and objects) performance of others. Other ways (intangible) are based on personal motivation and include a common viewing on goals, interest in results, understanding of social accountability, consensus searching, reasoned communication and etc.

The result of consolidation complex structure we can see in the modern Russian society, when dramatic transformations in all social spheres which followed Soviet system destruction and irresponsible reforms of 1990s, has had an impact on processes of social reproduction and on the system of consolidation principles in particular.

For the problem of consolidation (or dissociation) to be understood in a better way, in the Russian society from methodological views and in accordance with research concepts provided by analysts from Irkutsk we specify two types (streams) of consolidarity: vertical, i.e. an agreement between the government and society 
and vice versa); and horizontal, i.e. an agreement inside communities and between communities which build up the society. We make a point that the efficiency of consolidation mechanisms in an ideal model can be obtained when two different streams complement each other, making the system more sustainable and strengthening its existence; "in case of one stream weakening the society unavoidably enter in a varying degree in misbalance when objective mechanisms of consolidation do not function already, but the social entire can stay integral for some time by force of phenomenon of social inertia" [7]. It is important to mention that vertical consolidation depends on deliberate initiative from the power and can be framed at will; a horizontal one has a natural format since can it be represented in a form of everyday engagement.

As T.I. Zaslavskaya, a sociologist, claims, "still, exclusive and important performers in modernisation processes are governmental agencies", and "the level of consolidarity reflects an ability of correspond strengths for political acts and interaction with other strengths as a broadly integration"[3. P. 61].

Historically a basis for solidarity in the Russian society was composed both by objective (geographical, industrial) and subjective factors (values and ideology manifested in a desire to identify oneself as a part of the "united world" (orthodox or soviet), reflected in people's conscious as common moral and spiritual constants and guides. Thus, we can speak about peculiar to Russia subjective perception of $i$ as a process and oughts as a main direction of social development determining a stable order (definite result-oriented).

We also bring to notice the concept of "spirituality" which now lies on the periphery of social conscience due to its identification with religiosity, but is still actual in the society in a form of request for moral values, balanced development of a person and can be kept current so far. We agree with the statement made by a philosopher L.P. Bueva who says that spirituality cannot be identified with religiosity: "In this case we would separate most of people from spiritual development, we would also narrow and deplete the concept of "spirituality". As Mrs Bueva continues, spirituality is "an integrative feature belonging to the sphere of life-purpose values, determining the quality, content and focus of human existence and a "human image" in every person" [1. P. 4]. A famous russian philosopher and culture expert M.S. Kagan thinks the same: "spirituality comes from the obedience to religious consciousness... and exists in two modifications, i.e. religious and secular. Since monasticism accepted as a life-style dedicated to service of God is the highest form of religious spirituality, then secular spirituality is expressed in a self-denying service to people. M.S. Kagan claims, that "spirituality is an attribute of a person as a performer and non-spirituality is a sign of their subject characteristics loss and devolution in a simple object resembling an animal or mechanism" [5. P. 102]. Oriented to such objects modern manipulation technologies of advertising, political propaganda and mass culture have maximum effect since their influence focuses on instincts of a person who has lost perception of "spirit" and "soul".

Highly important to underline that at all times a traditional philosophical idea of Russia represents social and philosophical origin of "spirit", "soul" and "spirituality" together with moral duty, with internal self-improvement and changes, with reason and sensibility integrity, freedom and responsibility. Thus, one of the most important part of Russian philosophy says that pursuance of unity through unanimity, not by opposition between unity and personal freedom, but through freedom of every soul in its desire to achieve the Spirit. "Indeed, it is Russian 
philosophy that has a special philosophic school called philosophy of spirituality which, according to Pavel Florensky, bears to unitary world view supporting opposition between principles of creative thinking and destructive entropy" $[10$. C. 20].

Following the analysis of definitions for spirituality [6. P. 37] we can conclude that ideals or beliefs, particular hierarchy of values or consciousness orientation are not identical to "spirituality". Spirituality does not serve neither as a description of consciousness, behaviour, acts or life [8. P. 21], "characteristic of a person" [9. P. 87] or "ability" [2. P. 28] nor as anything else, but first of all as a part of spiritual sphere of social life revealing in creating and social relations improvement. In other words, spirituality can be described as an ideological principle of consolidation which points the life of society at self-improvement and process of harmonization of relations between social actors and relations between nature and society.

We claim that spirituality, within a sufficient development of its concept from social and culturological point of view, may well become ideological principle of horizontal consolidation in the modern Russian society, constructed through the system of education as a leading factor in personal life style formation. As a result of complete destruction of mechanism of social development that took place in the anarchic system of 1990s, now we cannot see any shared idea about deference between good and evil, we are unfamiliar to sympathy, justice, sorrow, mercy or kindness.

Formation of consolidation mechanism holds a number of problems which gather their pace by influence of globalization, social transformations, crises in economical, political, cultural and etc. spheres, appeared subsequently after the destruction of soviet society where Russian environment was integrated. After almost quarter of a century since Russia has becomeindependentprocessesofdeconsolidation still exist, i.e. a risk of destruction still exists in many former Soviet republics. For example today's events in Ukraine broadly represent the result of former ties breaking and demonstrate a probable scenario when vertical consolidation mechanisms collapse determining misbalance of horizontal channel. It is peculiar for this example that, internal contradictions are actively inspired externally. Apparently, for external forces, which have their own interest in a region, well-being of people and state integrity are not a goal in themselves. For this reason there is no efficient help in arrangement of conflicts and consolidation of the society, rather through controlled mass media and Internet resources they mount tension. Consequently, internal misbalance accompanied with civil conflicts increases due to mains geopolitical actors who attach labels "terrorist" and "peaceful demonstrator" depending on what information result is needed. At the same time impact, made on the society inside the state, has an obvious forcible form, i.e. they create an enemy image and use terror (deterrence against political enemies). Thus, temporal power deflects population from pushing to lower standard of living; tries to avoid responsibility for its failure to provide a background for a constructive dialog, for aggravation of deconsolidation process between Western and Eastern Ukraine and also for absence of opportunities to keep political and economical independence in the state and prevent Ukrainians from becoming a counter weapon to Russia.

In this context, attempts from the side of geopolitical powers directly or indirectly supporting Russophobia to plunge post-Soviet areas into an open confrontation are considered to be symptomatic and analysed as a currently important threat reflected in increasing of 
terrorism acts oriented on destabilization and deconsolidation of the Russian society.

Actions from the side of many world political performers (legally elected governments, political parties, etc.) intended to internal communities development, but shaking the leading position of the USA in the current system of the world order are identified as terror attacks. At the same time, support for violent overthrow of governments in sovereign states, made in order to maintain hegemony (particular order), is recognized as a struggle for democracy and human rights. Probably, the USA officials neglect the typology of terrorism and use this word as a signal for their "partners", specifying an object which violate corporate interests and which must be under the deterrence. We think, those political analysts are right who consider such behaviour as an active stage of the information war, since the usage of disinformation, for example, facts fabrication on massive weapon development in Iraq.

On the ground of analyzed definition and typology we can say about spread of terrorism and its becoming a global source of social entropy. Consequently, in order to minimize terrorist threats, countermeasures should be brought into action in all spheres according to their variety. This is impossible to achieve without united efforts, building of consolidation mechanisms inside the power and between economical, political, educational and other spheres of social life.

Thus, a priority in reaction to information dissemination as a mean and violence justification should be a planned development of such a system if vertical consolidation ideas that as social dialog platforms growth could be caught at horizontal level and progress independently, forming positive public opinion without government forces. Of course, Olympic Games and other momentous events held in this country recently, have had consolidation effect, but its selfproduction is impossible over a long term period. In front of a widespread outside information and physiological aggression finding its expression in a severe Russophobia, the state stays almost weak unless initiatives from the government are not supported by the civil society, academic community, business structures, educational agencies and mass media. Current means of communication provide opportunity to exclude imitation of an open dialog aimed at the result between the power and society or between social actors.

Speaking about effective opposition between ideology of violence and its fast spread in information space whether it is social networks or series, we would like to offer a set of criteria for the power at all levels. Firstly, it is a maximum assistance to young generation (arrangement of feedbacks, real opportunities for social initiatives implementation). Secondly, there should be motivation for expert researches and engagement of bloggers in order to detect fraud dissemination, slander or so called "information stuffing", i.e. providing of information which certainly will attract public attention. Thirdly, a focused sensitization work oriented at target audiences should be organized.

In such a way, spirituality plays an essential part in social consolidation. However, it would be a mistake to say that human entity could be narrow down to leading constants of being and then analyzed as an invariant or ahistoric state. During different periods of time the humanity characterized by its unity, which differentiated quantitatively and qualitatively in content volume and regimes [2. P. 28]. 


\section{Referencies}

1. Bueva L.P. Duhovnost' i problemy nravstvennoj kul'tury [Spirituality and Problems of Moral Culture] // Voprosy filosofii. 1996. №2. Pp .4-5.

2. Burbulis G.Je., Kemerov V.E. Duhovnost' i racional'nost' [Spirituality and Rationality]. M., 1986. P. 28.

3. Zaslavskaja T.I. Sovremennoe rossijskoe obshhestvo: Social'nyj mehanizm transformacii [Modern Russian Society: Social Mechanism of Transformation]. M. 2004. P. 61.

4. Kagan M.S. Ne mogu molchat'. Izbr. tr.: $\mathrm{v} 7$ t. Trudy po problemam teorii kul'tury [Works on the Problems of Culture]. SPb., 2007. T. 3. Pp. 719-723.

5. Kagan M.S. O duhovnom. Opyt kategorial'nogo analiza [About Spiritual. The Experience of Category Analysis] / Voprosy filosofii. 1995. №9. P. 102.

6. Kozlova, M. V. Problemy duhovnosti v kontekste sociokul'turnogo krizisa sovremennogo obshhestva [The Problems of Spirituality in the Context of Sociocultural Crisis of Modern Society] / Vestnik Orlovskogo gosudarstvennogo universiteta. Ser. Novye gumanitarnye issledovanija Orjol, 2011g. №1(15). Pp. 366-368.

7. Karmadonov O. A., Zverev M. K. Konsolidacija rossijskogo obshhestva: potoki i pregrady: monografija [Consolidation of Russian Society: Trends and Barriers: Monograph. Irkutsk : Izd-vo ISU. 2012. P. 125.

8. Fedotova V. G. Duhovnost' kak faktor perestrojki [Spirituality as a Factor of Perestroika] / Voprosy filosofii. 1987. № 3. P. 25.

9. Holostova T.V. Problema duhovnosti [The Problem of Spirituality] // Metodologicheskie problemy izuchenija cheloveka v marksistskoj filosofii. L.: Izd-vo LSU, 1979. P. 87.

10. Homutcov S.V. Duhovnost' i ejo antipod: avtoref. dis. ... d-r. filos. Nauk [Spirituality and its Antipode: PhD Thesis]. Barnaul: AltGU. 2009. P. 20.

11. Jacenko M.P. Istoricheskie aspekty globalizacii kak upravljaemogo processa [Historical Aspects of Globalization as Controlled Process] // Vestnik Orlovskogo gosudarstvennogo universiteta. 2011. №5(19). P. 225. 


\title{
Духовная составляющая консолидации общества
}

\section{в глобальном мире}

\author{
М.В. Козлова \\ Сибирский федеральный университет \\ Россия, 660041, Красноярск, пр. Свободный, 79
}

В статье осуществлена попытка сочиально-философского анализа перспектив противодействия современным террористическим угрозам информационного типа посредством воздействия на процессы консолидации российского общества. В результате исследования сделан вывод о характерной связи между преобладающими в обществе консолидируюшими идеями и уровнем устойчивости перед деструктивным манипуляционным воздействием со стороны террористов (идеологов насилия). Результаты исследования могут быть применены в качестве дополнений к существующим рекомендациям по противодействию террористическим угрозам, обеспечению сочиокультурной безопасности.

Формирование механизма социильной консолидации заключается в разрешении противоречий, обусловленных природой общественных отночений, между господством и подчинением, насилием (принуждением) и доброй волей, разногласием и согласием. Консолидация является основополагаюшим условием существования общества, его жизнедеятельности и способности к воспроизводству. При этом характер её реализации зависит от множества факторов: технологических, экономических, политических, культурно-исторических и других.

Для лучшего понимания проблем, связанных с консолидацией (или разобщением), в российском обществе с методологических позиций в соответствии с положениями исследования иркутских ученых обозначим два типа (потока) консолидированности: вертикальный (согласие власти с обществом и наоборот) и горизонтальный (согласие внутри сообществ и между сообществами, из которых формируется общество в целом). Важно подчеркнуть, что вертикальная консолидация зависит от сознательной инициативы власти и может произвольно конструироваться; горизонтальная - имеет естественный характер, так как выражается в виде форм повседневного взаимодействия.

В статье обращается внимание на понятие «духовность», которое ушло на периферию общественного сознания в связи с отождествлением его с религиозностью, но которое пока ешё сохраняет востребованность в нашем обществе в форме запроса на нравственные ценности, всестороннее развитие личности и ещё может быть актуализировано.

Особо в статье подчеркивается тот факт, что традиционная философская мысль России неизменно связывает социально-философские истоки понятий «дух», «душа» и «духовность» с нравственным долгом, со сложной внутренней работой и преображающим результатом, с нераздельностью разума и чувства, свободой и ответственностью. Стремление к единству через единодушие - не через призму противопоставления единства и свободы личности, а без принуждения, через свободу каждой души в своём стремлении к единому Духу - вот одно из важнейших положений русской философии.

Автор статьи исходит из того факта, что духовность, при достаточной сочиильнокультурологической разработке понятия, могла бы стать идейным принципом горизонтальной консолидации современного российского обиества, воспроизводимого через систему образования, которое выступает в качестве ведущего фактора формирования и утверждения образа жизни человека. В результате полного разрушения механизма сочиального конструирования реальности при анархическом порядке 90-х годов сегодня мы не имеем коллективных представлений о различии добра и зла, о том, что такое сострадание, справедливость, жалость, милость, доброта.

Формирование консолидаџионного механизма, как доказано в статье, таит множество проблем, которые сегодня усугубляются глобализаичионным давлением, соичиальными трансформациями, 
кризисомэкономической, культурно-политическойидругихсфер, развернувиихсяврезультате распада советского общества, в которое был интегрирован российский социум. Процессы деконсолидации спустя почти четверти столетия после обретения Россией независимости не остановились: угроза распада вслед за советским сохраняется во многих постсоветских обществах. Например, ситуация на Украине во многом является следствием разрыва прежних связей и демонстрирует вариант развития событий, когда вертикальные консолидирующие механизмы выходят из строя, детерминируя разбалансировку горизонтального потока. В данной связи попытки ввергнуть в открытое противостояние постсоветские общества со стороны геополитических сил, противостоящих России (явная и неявная поддержка русофобии), представляются нам симптоматичными и рассматриваются как актуальная угроза усиления различных проявлений терроризма, направленных на дестабилизацию и деконсолидацию российского общества.

На основании анализа последних мировых событий автор приходит к выводу о разрастании терроризма, становлении его в качестве глобального источника сочииальной энтропии. Для того чтобы минимизировать террористические угрозы, противодействие ему должно осушествляться по всем направлениям в соответствии с его многообразными формами, что невозможно без общего координирования действий, формирования консолидационного механизма внутри власти, между экономической, политической, образовательной и другими сферами общественных отношений.

Ключевье слова: идейные принц̧ипь, солидарность, консолидацчия, терроризм.

Научная специальность: 09.00.00 - философские науки. 